к.т.н., ст.н.с. РАН, главный специалист ИСЭМ СО РАН,

профессор кафедры «Электроснабжение промышленных предприятий»,

ФГБОУ ВО «Ангарский государственный технический университет», тел.: 89025698207

Коновалов Юрий Васильевич,

к.т.н., доцент кафедры «Электроснабжение промышиенных предприяитй», ФГБОУ ВО «Ангарский государственный технический университет», е-таil:

yrvaskon@mail.ru

Тюрюханов Сергей Фомич

аспирант Института систем энергетики им. А.Н. Мелентьева СО РАН, тел.:

89648145091

Хайдуков Валерий Валерьевич

аспирант Института систем энергетики им. Л.А. Мелентьева СО РАН, тел.: 89248289838

ТОПЛИВНО-ЭНЕРГЕТИЧЕСКИЙ КОМПЛЕКС ИРКУТСКОЙ ОБЛАСТИ

В СОВРЕМЕННЫХ УСЛОВИЯХ. ПРОБЛЕМЫ И ПЕРСПЕКТИВЫ РАЗВИТИЯ

Golovshchikov V.O., Konovalov Yu.V., Tjurjuchanov S.F., Hajdukov V.V.

\title{
FUEL AND ENERGY COMPLEX OF IRKUTSK REGION IN CONTEMPORARY CONDITIONS. PROBLEMS AND PROSPECTS FOR DEVELOPMENT
}

Аннотация. В статье рассматривается формирование энергетики Иркутской области (ИО), структура её топливно-энергетического комплекса (ТЭК). Проанализирована современная топливная ресурсная база региона и её проблемы. Рассмотрены все составляющие ТЭК: нефтегазовая, угольная и электроэнергетика. Выделены наиболее проблемные места в каждой из составляющих ТЭК и предложены некоторые рекомендащии по их устранению. Показаны также новые риски и угрозы для ИО, связанные с ТЭК региона.

Ключевые слова: топливно-энергетический комплекс, ресурсная база, электроэнергетика, теплоэнергетика, тарифы, энергетические компании, потребители энергии.

Abstract. The article discusses the formation of the power industry of the Irkutsk region (IR), the structure of its fuel and energy complex (FEC). The modern fuel resource base of the region and its problems are analyzed. All components of the fuel and energy complex are considered: oil and gas, coal and electric power. The most problematic areas in each of the components of the fuel and energy complex are highlighted and some recommendations for their elimination are proposed. Also shown are new risks and threats to IRs associated with the fuel and energy complex region.

Keywords: fuel and energy complex, resource base, electric power industry, heat power engineering, tariffs, energy companies, energy consumers.

В современном мире никто не ставит под сомнение огромную важность топливноэнергетического комплекса (ТЭК) для мировой экономики отдельных стран и их регионов. Глобальные тренды, тенденции, риски и угрозы и их специфика в той или иной мере отражаются на функционировании и развитии ТЭК и его влиянии на социальноэкономическую, технологическую и даже политическую ситуацию всех развитых стран. Это в полной мере относится к Российской Федерации (РФ) и к субъектам РФ, имеющим крупные ТЭК. К таким субъектам относится и Иркутская область (ИО), которая по масштабам своего совокупного ТЭК (база энергетических ресурсов, электроэнергетическая система, структура потребления энер- горесурсов и т.д.) входит в десятку крупнейших в стране, а по масштабам электроэнергетической системы делит третье-четвертое место в РФ. ТЭК ИО рассматривался во многих работах, прежде всего в работах Института систем энергетики им. Л.А. Мелентьева (ИСЭМ) СО РАН, так как проблемы ТЭК не только ИО, но и РФ в целом, являются научными направлениями этого НИИ. Представляет несомненный интерес монография по ТЭК ИО, вышедшая в 2013 году [1]. Но ситуация последних лет изменила некоторые ключевые положения, проработанные в упомянутой работе. Именно поэтому необходимо проанализировать современную ситуацию с ТЭК в ИО, выявить «узкие места», оценить их влияние на социально-экономическое раз- 
витие региона. Представляется целесообразным напомнить краткую предысторию создания ТЭК ИО для сопоставления с современной ситуацией. Формирование ТЭК ИО началось в пятидесятые годы прошлого века. Однако и в довоенный период в ИО были энергетические объекты, например, Иркутская угольная городская электростанция, небольшие электростанции и в других населенных пунктах; развивалась и угледобыча. В конце 60-х годов в СССР было принято решение о создании Районных энергетических управлений (РЭУ), которым практически во всех регионах страны было передано в эксплуатацию большинство крупных энергообъектов (электростанции, крупные котельные, электрические и тепловые сети). При этом, например, ТЭЦ по-прежнему размещались на территории соответствующего промышленного предприятия. В 1968 году началось формирование энергетического комплекса ИО, когда было создано РЭУ «Иркутскэнерго», в состав которого вошли существующие на тот момент электростанции, а также (уже позднее) высоковольтные сети («Предприятие высоковольтных сетей» ПВВС). К концу семидесятых годов РЭУ «Иркутскэнерго» стало мощной энергетической компанией. Такие РЭУ в современной терминологии называются «Вертикальноинтегрированные компании» с жестким управлением сверху вниз. Одновременно с «большой энергетикой» функционировало множество мелких тепловых источников (котельные и бойлерные) и распределительные электросети низких классов напряжения (35 кВ и ниже), которые образовали так называемую «коммунальную энергетику» с областной и муниципальной формами собственности. В этот период ресурсная топливная база региона была представлена угольными разрезами, которые функционировали и развивались в Черемховском и Тулунском районах ИО, а также ряд мелких месторождений в других регионах области. В семидесятых годах началась достаточно скромная (по объемам) эксплуатация Марковского нефтегазоконденсатного месторождения («легкой нефти»), открытого в 1962 году, а в конце восьмидесятых годов прошлого века в район п. Жигалово было открыто крупнейшее на востоке РФ Ковыктинское газоконденсатное месторождение с запасами около 2 трлн. куб. м. газа, которое в будущем (как будет показано ниже) станет одним из основных месторож- дений для выполнения экспортных поставок природного газа в КНР.

До 1992 года, когда начался полный слом плановой экономики и социалистических форм управления народным хозяйством, сложившихся в советский период, ТЭК СССР в целом и ТЭК ИО в частности достаточно успешно справлялись со своими задачами по надежному снабжению потребителей необходимыми энергоресурсами: электрической и тепловой энергией и топливом. Надо признать, что существовавшая жесткая вертикаль управления энергетикой (Минэнерго СССР - конечное энергопредприятие), которая получила название «командноадминистративное управление», в целом обеспечивала суммарный народохозяйственный эффект, так как и энергетика и потребители (юридические лица) были в государственной собственности. Однако в энергетике стали накапливаться проблемы, обострившиеся к концу 80-х годов, которые являлись следствием негативных социальноэкономических тенденций в СССР. Не стало хватать оборотных средств, срывались сроки ввода новых объектов и модернизация действующих, быстрыми темпами старело оборудование, медленно внедрялись новейшие технологии. А главное - не было материальных стимулов работать эффективно, так как все основные показатели устанавливались централизовано и жестко контролировались, а положительные результаты отдельных энергопредприятий распределялись на всю энергетическую отрасль. Надо отметить, что в семидесятые годы прошлого века страна имела большие доходы от экспорта нефти, которыми мы не смогли эффективно распорядиться. В этот же период первый критический момент в электроэнергетике ИО проявился в 1992 году, когда вышел указ Президента РФ (№923) об акционировании и создании РАО «ЕЭС России», которое должно было управлять функционированием и развитием всей электроэнергетической отраслью. Иркутской области, благодаря первому Губернатору Ю.А. Ножикову и топменеджерам РЭУ «Иркутскэнерго», удалось акционироваться вне состава РАО «ЕЭС России». Это первоначально был положительный момент, так как регион сохранил в своей структуре одну из крупнейших энергокомпаний. Но практически сразу начались конфликты на федеральном уровне с обвинениями в адрес ИО, что «область нарушила 
указ Президента». Более того, не находясь в составе РАО «ЕЭС России», где контрольный пакет акций этого холдинга принадлежал РФ, в начале двухтысячных годов «самостоятельность АО «Иркутскэнерго» облегчила переход компании в частные руки структурам О.В. Дерипаски (БАЗЭЛ), которые в простонародье называются «алюминьщиками».

К началу двухтысячных годов назрела необходимость реформы электроэнергетики России, которая официально началась с выхода Постановления Правительства РФ № 526 (июль 2001 г.) «О реформировании электроэнергетики» и была закреплена Федеральным законом №35 (2003 г.) «Об электроэнергетике», целью которых было перевод отрасли на рыночные принципы. В настоящее время большинством научнотехнического сообщества РФ признается, что основные цели реформы, которые по смыслу были правильными, не выполнены: рынки созданы, а эффективных конкурентных отношений нет, продолжается неудержимый рост цен (тарифов) на электрическую и тепловую энергию, сохраняется перекрестное субсидирование, по-прежнему стареют основные фонды, полноценных конкурентных отношений на рынках топлива нет, и т.д. [28]. Надо отметить, что реформа затронула в первую очередь крупные энергетические компании, финансово-экономическое состояние которых в целом было удовлетворительным. Что же касается объектов «малой энергетики» («коммунальной»), то их состояние до реформы и после её проведения почти не изменилось: их финансирование продолжалось по остаточному принципу и, как следствие - износ основных фондов во многих регионах приблизился к критическому, что привело и приводит к постоянным нарушениям процесса электро- и теплоснабжения потребителей. И Иркутская область не является исключением. Согласно Ф3 №35 все вертикально-интегрированные электроэнергетические компании должны были быть разделены по видам деятельности: на конкурентные - производство энергии и энергосбытовая деятельность и на регулируемые государством - передача электроэнергии по электросетям и диспетчерское управление. АО «Иркутскэнерго» также было вынуждено разделиться, но в отличие от других АОэнерго в РФ разделенные структуры сохранили свою аффилированность. После разде- ления образовались следующие юридически самостоятельные структуры: АО «Иркутскэнерго», состоящее из исполнительной дирекции, ГЭС и «теплового бизнеса» (ТЭЦ и тепловые сети); АО «Иркутская электросетевая компания» (ИЭСК); ООО «Иркутская энергосбытовая компания» (ИЭСБК), а также ремонтные, строительные и вспомогательные подразделения, которые были выведены как «непрофильные виды бизнеса». Подобное разделение привело к росту операционных издержек, так как в каждой отдельной компании были сформированы отдельные управленческие структуры, а также к частичной потере эффективного взаимодействия, особенно между ремонтными и другими структурами, включая использование специальной техники и оборудования. В этот же период АО «Иркутскэнерго» стало «энергоугольной компанией», фактически подчинив себе «Востсибуголь» и став собственником некоторых других угольных разрезов, например, в Красноярском крае. Можно считать, что это было положительным решением, так как компания стремилась минимизировать свои затраты на закупках угля для ТЭЦ. За последние годы организационноструктурные преобразования бывшего АО «Иркутскэнерго» продолжались. Несколько лет назад была создана компания «ЕвроСибэнергоГидрогенерация» (являющаяся структурой «ЕвроСибэнерго»), которой были переданы в эксплуатацию все три ГЭС Ангарского каскада ИО. К началу 2019 года весь персонал этих ГЭС был переведен в «ЕвроСибэнергоГидрогенерация». Что касается «теплового бизнеса», то для управления им было создано ООО «Байкальская энергетическая компания» (май 2013 года), которое в настоящее время управляет всеми ТЭЦ бывшего АО «Иркутскэнерго». Последствия, а также возможные риски и угрозы для ИО этих преобразований будут проанализированы ниже в данной статье.

Существующее состояние энергетического комплекса ИО и перспективы его предполагаемого дальнейшего развития приведены в двух документах: «Стратегия социально-экономического развития (ССЭР) Иркутской области на период до 2036 года» (проект 2020 г.) и «Схема и программа развития электроэнергетики (СИПР) Иркутской области на период 2022 - 2026 года», утвержденная указом Губернатора ИО №128-уг от 29.04.2021 г. Следует отметить, что проект 
«Стратегии социально-экономического развития ИО» не принят и продолжает обсуждаться в различных общественных и государственных структурах. По мнению авторов, основным недостатком проекта ССЭР является то, что стратегия рассматривает только один сценарий развития ИО: инновационный (постиндустриальный) сценарий, который (далее по тексту ССРЭ «...предусматривает создание и приоритетное развитие высокотехнологичных и наукоемких отраслей новых технологических укладов - газохимии, фармацевтики, авиационной промышленности. Основная задача инновационного сценария развития - проведение «второй индустриализации» Иркутской области путем модернизации существующих и строительства новых промышленных предприятий»). Упоминаемый в ССЭР консервативный (индустриальный) сценарий развития ИО, не рассматривается, что является ошибкой, если учесть все вызовы и угрозы, появившиеся в последнее время. Ниже это будет проиллюстрировано на примере «газификации ИО» и других проблем, связанных с ТЭК. В то же время содержащаяся в «проекте ССЭР» и СИПР информация по ТЭК ИО, вполне достаточная для оценки состояния, выявления «узких мест» и перспектив развития ТЭК. Ценность этой информации заключается в том, что она охватывает все составляющие ТЭК ИО в целом и энергетики в частности, включая «большую и малую энергетику», в том числе и возобновляемые источники энергии. Выделим и проанализируем наиболее актуальную информацию ССЭР и СИПР по ТЭК ИО.

Нефтегазовая составляющая ТЭК. Основные перспективные для добычи месторождения находятся в северных, северозападных и центральных районах ИО. Реальные запасы природного газа различных месторождений составляют более 2 трл. куб.м., крупнейшее из которых является Ковыктинское газоконденсатное месторождение (КГКМ). Следует отметить, что в ИО низкая разведанность суммарных углеводородных ресурсов: по нефти составляет менее $9 \%$, по природному газу - около $15 \%$, при среднероссийском уровне около $50 \%$. Природный газ ИО является уникальным, так как кроме простейшего метана содержит ценные компоненты: этан, пропан, бутан и гелий, которые могут стать сырьевой основой создания в ИО газохимической промышленности. До- бычу природного газа (свободного и попутного) на территории ИО в настоящее время ведут более десяти компаний, крупнейшими из которых являются: АО «Верхнечонскнефтегаз», ООО «ИНК», АО «НК Дулисьма», ПАО «Газпром». На эксплуатируемых нефтегазовых и нефтяных месторождениях попутный газ составляет значительную долю от всего добываемого газа. Однако при этом более половины этого газа сжигается в «факелах». Из-за накладываемых на предприятия штрафных санкций за сжигание попутного газа «в факелах», объемы его полезного использования постепенно увеличиваются. Некоторые наиболее крупные компании ведут обратную закачку попутного газа в пласты, а некоторые перерабатывают его в товарную продукцию, например, в бытовую пропанбутановую смесь. Наибольшую активность в сфере «газового бизнеса», включая создание газохимического производства, проявляет Иркутская нефтяная компания (ИНК) в районе г. Усть-Кута, где началось сооружение завода по производству полимеров, в качестве сырья для которого используется природный газ локальных месторождений (не КГКМ). Началась также локальная газификация социальной сферы в районе КГКМ (п. Жигалово), перевод общественного автотранспорта и одной котельной на газ в г. Братске.

Вместе с тем на фоне положительных примеров развития газодобычи в ИО имеется множество принципиально важных проблем, которые не рассматриваются в Стратегии. Это касается массовой газификации ИО. Анализ показал, что эта проблема существует более двадцати лет с момента открытия КГКМ в конце 80-х годов прошлого века. Каждый новый Губернатор ИО обещает решить эту проблему, предпринимая определенные усилия на федеральном уровне. Однако ситуация с газификацией ИО выглядит следующим образом. Природный газ КГКМ, после завершения строительства участка магистрального газопровода «Ковыкта - Сила Сибири», будет направлен на заполнение газопровода «Силы Сибири», запущенного в декабре 2019 года и который в настоящее время заполняется газом Чаяндинского месторождения в Якутии. Весь газ идет на выполнение экспортных поставок в Китай. Без газа Ковыкты договорные экспортные поставки в объеме 38 млрд. куб.м. в год не могут быть выполнены, тем более, что на Чаян- 
динском месторождении появились проблемы с добычей («пустые скважины»). Поэтому вероятность строительства газопровода «Ковыкта-Саянск-Иркутск» ничтожна мала. По предварительным экспертным оценкам потребность ИО в природном газе к 2030 году должна составить около 10 - 15 млрд.куб.м. в год, если развивать газохимию, перевести все ТЭЦ и большинство угольных и мазутных котельных на газ и газифицировать домохозяйства. Необходимо отметить, что из-за «специфики» финансовоэкономических взаимоотношений РФ и Китая в среднесрочной и тем более в долгосрочной перспективе, могут возникнуть проблемы с экспортной нефтегазовой политикой РФ [9]. Определенные надежды на массовую газификацию ИО появились в 2019 году, когда президент поставил очередную задачу газифицировать большинство регионов России (социальную сферу и население), так как обладая крупнейшими месторождениями газа, этот важнейший ресурс в основном идет на экспорт, поскольку дает существенное наполнение бюджета РФ. Начался очередной цикл совещаний, переговоров, рамочных соглашений и т.д., но реальный процесс начался только в конце 2020 года, когда был запущен процесс бесплатного подключения к газовым сетям домохозяйств. На крупном совещании по различным вопросам, под руководством Президента в июле 2021 года (в г. Кемерово), результаты выполнения указа Президента по скорейшей газификации страны озвучивал заместитель председателя Правительства РФ А.В. Новак (бывший Министр энергетики). По его словам, в целом, работа идет достаточно успешно, чему способствовало в том числе и создание оперативных штабов для управления процессом газификации. Такой штаб был создан и в ИО на основании распоряжения Губернатора №220-р от 18.07.2021 г., в который вошел один из авторов этой статьи (В.О. Головщиков). По состоянию на конец октября 2021 года «штаб» собирался только один раз не в полном составе, для решения частных вопросов. Можно считать, что вопрос «сплошной газификации ИО» не будет никогда решен, так как: 1) трасса вероятного сооружения газопровода «Сила Сибири-2» (газ Западной Сибири в Монголию) минует ИО; 2) по мнению Минэнерго РФ, топливно-энергетический баланс ИО основан на дешевом угле, поэтому существующие цены на природный газ не конку- рентны. Планировать газификацию региона на основе сжиженного природного газа (СПГ) в настоящее время также бесперспективно, так как нет ресурсной базы и соответствующей структуры для сжижения. А с учетом «логистики» цена такого СПГ будет высокой.

Что касается развития нефтяной отрасли в ИО, то оно ограничивается в основном увеличением добычи нефти: за десять лет (к 2019 году) добыча увеличилась в 11 раз и составила около 18 млн. тонн. При этом вся добываемая нефть в ИО, поступает в магистральный нефтепровод «Восточная Сибирь Тихий Океан» (BCTO) для экспортных поставок.

Угольная составляющая ТЭК. По данным, приведенным в ССЭР, запасы угля в ИО составляют почти 28 млрд.т.; из них более $70 \%$ каменные угли и $30 \%$ бурые угли. По оценкам некоторых специалистов запасов угля в ИО хватит почти на 600 лет при существующих темпах добычи. В ИО не наблюдается процесс активизации угольной отрасли, обусловленный геологическими причинами, неудовлетворительным качеством углей, которые требуют обогащения. Дополнительными причинами являются устаревшее оборудование, минимальная потребность в наращивании добычи угля и т.д. Основной угледобывающей компанией является ООО «Компания Востсибуголь», входящая в холдинг АО «ЕвроСибЭнерго» (один из крупнейших в РФ). В 2018 году компанией было добыто около 14 млн.т. угля. Несмотря на то, что по имеющимся и разведанным запасам угольная отрасль ИО могла бы добывать 50 млн.т. в год, по оценкам, приведенным в ССЭР, годовая добыча не превысит 15 млн.т. По мнению авторов статьи (и других специалистов) функционирование и развитие угольной отрасли в ИО зависит от многих факторов, включая внешние. Наблюдающийся с середины 2020 года «угольный ценовой бум», и прежде всего в Северо-Восточной Азии, привел к тому, что Президент РФ поставил задачу увеличить к 2024 году пропускную способность БАМа и Транссиба до 180 млн.т. в год. Из этого объема основную долю должны составить экспортные поставки угля из Кузбасса и Якутии. Перспективным может оказаться наращивание экспорта угля и из ИО. Однако все эти намерения по модернизации прежде всего БАМа, которые начали реализовываться, рассматриваются в 
среднесрочной перспективе (5-10 лет). Возникает естественный вопрос: «А что дальше?». «Угольный бум» вызван разрывом контрактов Китая с Австралией, газовыми проблемами в Европе огромным ростом цен на газ, которые потребовали снова активизировать «угольную генерацию электроэнергии» и т.д. Но никто в мире (и в РФ) не ставит под сомнение неизбежный процесс ухода от сжигания угля и нефтепродуктов и переход к возобновляемым источникам энергии (ВИЭ) [10]. В то же время перспективы сохранения угольной составляющей ТЭК ИО, хотя бы в существующем виде, весьма благоприятные, так как уход от «угольной генерации» (ТЭЦ и котельные) и переход на природный газ, по выше приведенным причинам, становится мало вероятным, даже в долгосрочной перспективе (10-15 лет). Немаловажным фактором становится и социальный аспект, так как резкое сокращение угольной отрасли в ИО потребует решать проблемы занятости в угледобывающих районах. Кроме того надо учитывать и такой важный момент - на упомянутом выше «июльском совещании» в Кузбассе Президент поставил задачу подготовить в этом основном угольном регионе России не менее 40 тыс. рабочих мест, не связанных с угольной отраслью. Можно предположить, что и руководство страны понимает неопределенность угольной отрасли РФ в будущем.

Энергетический комплекс ИО. Этот комплекс включает объекты производства электрической и (или) тепловой энергии различной мощности и использующие различные виды энергоресурсов: гидроэнергия, уголь, мазут, газ, дрова и отходы лесопереработки, а также электрические и тепловые сети.

По данным ССЭР для производства тепловой и электрической энергии (ТЭЦ и котельные) в 2018 году потребовалось почти 11 млн.т. у.т. При этом доля угля в структуре топлива на ТЭЦ и котельных составила около $73 \%$; не менее $25 \%$ составляют прочие виды топлива. Это существенная величина, которая объясняется широким их использованием на собственных энергоисточниках крупных промышленных предприятий (Лесопромышленные комплексы, Ангарская нефтехимическая компания), включая отходы производства. Надо отметить, что это положительный фактор, так как вовлекаются в производство энергии вторичные энергоре- сурсы. На ТЭЦ и котельных ИО применяются главным образом угли иркутских месторождений - более $70 \%$. В существенно меньших объемах сжигаются канскоачинские, кузнецкие, и хакасские угли. Следует отметить, что поскольку на выработку тепловой и электрической энергии на ТЭЦ и котельных сжигается в основном уголь, то важнейшей проблемой становятся вопросы экологии. Это прежде всего касается центральных и южных районов ИО, приближенных к природоохранной центральной зоне о. Байкал. Поэтому при сохранении «угольной генерации энергии» (а это, как показано выше - минимум на среднесрочную перспективу), необходимо направить усилия на глубокую модернизацию теплоисточников с применением новейших технологий сжигания топлива, например: «вихревой кипящий слой».

Электроэнергетика. Эта составляющая ТЭК ИО является важнейшей для социальноэкономического развития региона, так как обеспечивает электрической и тепловой энергией все группы потребителей. Как известно, «Иркутская энергосистема» (региональная энергосистема - РЭС) является одной из крупнейших в Единой электроэнергетической системе РФ (ЕЭС России) и входит в объединенную электроэнергетическую систему (ОЭС) Сибири. РЭС ИО входит во вторую ценовую зону («сибирскую») оптового рынка электрической энергии и мощности страны (ОРЭМ). Согласно информации ССЭР и СИПР производство электроэнергии РЭС ИО составляет не менее $30 \%$ суммарного производства Сибирского Федерального округа. В структуре РЭС ИО: 4-е ГЭС и 15 ТЭС с суммарной установленной мощностью 9,1 ГВт и 4,04 ГВт соответственно. В 2020 году гидравлические и тепловые электростанции ИО произвели 59,7 млрд. кВт.ч (ГЭС: 47, 7 млрд. кВт.ч и ТЭС 12 млрд. кВт.ч). Это значительный объем, но установленная мощность генерирующего оборудования электростанций позволяет вырабатывать существенно большие объемы электроэнергии и в первую очередь на ТЭЦ. Необходимо выделить важные моменты в функционировании и развитии генерации электроэнергии в РЭС ИО: 1) Необходима полномасштабная модернизация тепловых электростанций - некоторые из них исчерпали свой ресурс. Отказ от плановопредупредительных ремонтов (ППР) и про- 
должение эксплуатации ТЭС (переход к «риск ориентированному управлению») возможен только при проведении качественной диагностики на основе цифровых технологий. 2) Необходимо тщательное обоснование сооружения газовой электростанции (включая потребность в электроэнергии) в районе г. Усть-Кута, о которой говорилось в течение ряда лет (Ленская ТЭС мощностью до 1200 МВт). Представляется целесообразным сооружение именно ГТУ-ТЭЦ для одновременного решения проблем теплоснабжения г. Усть-Кута. 3) Пока не совсем ясна необходимость строительства Тельмамской ГЭС (до 450 МВт) в Бодайбинском районе (выше Мамаканской ГЭС), так как дефицит электроэнергии в золотодобывающем районе можно более быстро ликвидировать сооружением необходимых ЛЭП. 4) Перспективным направлением в развитии электроэнергетики может (и должна) стать модернизация крупных и средних котельных с переводом их в режим когенерации (выработка тепловой и электрической энергии), что существенно сокращает затраты топлива и повышает КПД энергоисточника. Электросетевой комплекс РЭС ИО, как составляющая электроэнергетики, содержит более 72 тыс. км. воздушных и кабельных линий различных классов напряжения: от 0,4 до 500 кВ. В регионе функционируют такие крупные электросетевые компании, как ПАО «ФСК ЕЭС» (Усть-Кутский район) и АО «Иркутская электросетевая компания» (ИЭСК), являющаяся основной ЭСК в ИО. В регионе также представлены 25 территориальных сетевых организаций (ТСО) разной эффективности (от достаточно успешных, до фактически банкротов), которые имеют официальные тарифы на свои услуги по передаче электроэнергии по распределительным электросетям напряжением 35 кВ и ниже. Если в электросетях высоких классов напряжения (110 кВ и выше) ситуация постепенно улучшается (как и везде в РФ), то в распределительных сетях в некоторых районах ИО она близка к критической из-за физического износа электросетей (линии, подстанции, комплекты защиты и автоматики и т.д.). Потери электроэнергии в сетях ТСО в среднем не менее $20 \%$. Из официальной информации, размещенной, например, на сайте крупнейшей ТСО ИО с областной формой собственности ОГУЭП «Облкоммунэнерго», а также из информации, приведенной в СИПР на 2020-2022 годы (упомянутой выше), следует, что износ основных фондов ОГУЭП ОКЭ не менее $80 \%$, что приводит к низкой надежности электроснабжения потребителей. А эта организация обеспечивает электроэнергией потребителей в большинстве регионов ИО. Проблемы ОГУЭП ОКЭ носят системный характер и существуют более десятка лет. Их решение (которые уже предлагались ранее $[6,11]$ ) требует политической воли высшего руководства ИО. По мнению авторов, что уже неоднократно предлагалось ранее, необходимо существенно сократить количество ТСО в ИО и консолидировать их электросетевые активы на базе наиболее успешных компаний, что предусмотрено распоряжением Правительства Российской Федерации от 03.04. 2013 года № 511-р. Это позволит уменьшить операционные расходы, повысит эффективность использования оборудования и техники, а также снизить конечный тариф (цену) на электроэнергию для потребителей за счет уменьшения составляющей платы за услуги по передаче электроэнергии по сетям, которая в среднем по РФ составляет около $50 \%$.

Неотъемлемой часть электроэнергетического комплекса ИО является электроснабжение в зонах отсутствия централизованного электроснабжения, которое обеспечивается множеством дизельных электростанций (ДЭС) различной мощности (от 30 кВт до 5 МВт (одна установка)) и с различным техническим состоянием (большинство предельно изношены). Эти ДЭС (суммарной мощностью $20 \mathrm{MB}$ ) требуют постоянного ремонта, поставок дорогого дизельного топлива и, как следствие - существенно нагружают бюджет непрерывными дотациями на закупку топлива и обслуживание ДЭС. Выходом из этой ситуации могут быть следующие направления: строительство сетей, для подключения к централизованной энергосистеме, использование местных ресурсов природного газа (с заменой существующих ДЭС на современные газопоршневые), а также широкое применение различных возобновляемых источников энергии. Если обобщить необходимые меры по ликвидации «узких мест» в электроэнергетике, и в первую очередь в электросетевом комплексе, то первоочередными мерами будут: 1) активизация процесса обновления сетей ТСО; 2) сокращение числа неэффективных ТСО; 3) борьба с технологическим и коммерческими потерями электроэнергии; 4) создание развитой 
системы учета электроэнергии (АИИС КУЭ); 5) постепенный переход к «умным сетям» на основе новейших технологий; 6) сооружение высоковольтных ЛЭП для электроснабжения районов ИО с планируемым ростом электрической нагрузки; 7) активизация процесса модернизации электроснабжения в изолированных районах ИО, в том числе и на основе внедрения ВИЭ и др.

Теплоснабжение. Эта составляющая энергетического комплекса ИО является также критически важной, так как область находится в зоне с низкими среднегодовыми температурами. По данным ССЭР и СИПР ИО теплоснабжение региона обеспечивается: двенадцатью ТЭЦ ПАО «Иркутскэнерго», тремя ТЭЦ других компаний (включая ТЭЦ БЦБК в г. Байкальске), на которые приходится более $60 \%$ выработки тепловой энергии. Кроме того в ИО функционирует почти 1000 промышленных и отопительных котельных, использующих различные виды органического топлива, а также около 200 электробойлерных. Совокупная установленная мощность всех теплоисточников ИО около 4 тыс. Гкал/час. Протяженность тепловых сетей в регионе почти 4 тыс. км. В настоящее время в ИО производится около 40 млн. Гкал тепловой энергии в год. Анализ показывает, что в сфере теплоснабжения ИО также существует множество проблем: износ тепловых сетей и мелких теплоисточников, разрегулированность теплосети во многих населенных пунктах, не соблюдение температурных графиков, использование дорогого мазута (нефти) в качестве топлива, нарастающий дефицит тепловой энергии в зонах массового жилищного строительства, эксплуатация большого количества мелких низкоэффективных теплоисточников и т.д. Эту ситуацию усугубляют и большие неплатежи населения за потреблённую тепловую энергию. Чтобы существенно увеличить эффективность функционирования и развития систем теплоснабжения в ИО, необходимо решать все перечисленные проблемы, хотя бы поэтапно и исходя из имеющихся ресурсов. Но представляется необходимым выделить две острые проблемы, решение которых растянулось на несколько лет. Теплоснабжение г. Байкальска: после закрытия Байкальского целлюлозно-бумажного комбината (БЦБК), тепловые нагрузки ТЭЦ БЦБК резко снизились, поэтому этот теплоисточник стал работать в неэффективном режиме оборудования (низкий КПД), обеспечивая только теплоснабжение г. Байкальска с многомиллионными дотациями на закупку угля. В течение последних десяти лет предлагались различные варианты решения этой проблемы: полная модернизация существующей угольной ТЭЦ, переход на газ, сооружение электробойлерных и даже применение ВИЭ (например, тепловых насосов). Руководство ИО настаивало на модернизации угольной ТЭЦ, так как ранее был разработан технический проект такой модернизации (а фактически строительство новой ТЭЦ) стоимостью несколько десятков миллионов бюджетных денег. Однако по экологическим причинам зоны о. Байкал, в современных условиях такой проект не может считаться приемлемым. Проведенные в течение трех последних лет исследования ИСЭМ СО РАН, в рамках федеральной целевой программы, связанной с проблемами центральной экологической зоны о. Байкал, показали, что наилучшим вариантом является сооружение в г. Байкальске нескольких крупных электробойлерных, не оказывающих воздействие на окружающую среду. Но есть и в этом случае крупная проблема. Это стоимость тепловой энергии, производимой на этих бойлерных. Если тариф (цена) на электроэнергию для этих теплоисточников будет как для юридических лиц ИО, а для населения стоимость тепловой энергии останется на прежнем уровне, то опять появляются большие выпадающие доходы бюджета ИО. Решение этой «ценовой проблемы» зависит только от федеральных органов власти. В последнее время появилась надежда, что положительное решение по тарифам (ценам) будет принято, так как в Правительстве РФ появилось понимание важности решения проблемы не только теплоснабжения г. Байкальска, но в первую очередь экологических проблем о. Байкал. Теплоснабжение г. Иркутска: в настоящее время основным источником теплоснабжения города является Ново-Иркутская ТЭЦ, мощность которой пока достаточна в настоящее время и на два-три года в перспективе (даже при сохраняющихся темпах жилищного строительства). Теплоснабжение объектов Ленинского района города обеспечивают также две крупные котельные: Котельная северного промышленного узла (КСПУ) и котельная Иркутского авиационного завода, которые не связаны друг с другом тепловыми сетями. В настоящее время эксплуатируется и большое 
количество мелких теплоисточников, особенно в правобережных предместьях г. Иркутска. Наличие только одного крупного теплоисточника делает систему теплоснабжения г. Иркутска крайне ненадежной и особенно после закрытия крупных мазутных котельных: в п. Энергетик (Свердловский район) и Центральной Кировской котельной (ЦКК - бывшая ТЭЦ-2). Подобная «оптимизация» была проведена руководством Иркутскэнерго, чтобы минимизировать затраты на теплоснабжение по требованию акционеров этой компании. В настоящее время фактически принято решение о закрытии КСПУ и начале реализации проекта по прокладке теплопровода от ТЭЦ-10 (в районе г. Ангарска) в северный район Ленинского района. По мнению авторов проекта, это повысит финансово-экономическую эффективность теплоснабжения, так как КСПУ является затратным теплоисточником. При этом инициаторы проекта утверждают, что тепловые потери в теплопроводе (длиной почти 20 км), с финансовой точки зрения, более приемлемы, чем эксплуатация КСПУ. Но никто не поднимает вопрос надежности этого проекта. Что будет, если произойдет авария на этом магистральном трубопроводе? Ведь консервация КСПУ, как резервного теплоисточника, не предусматривается. Нерешаемой проблемой остается вопрос о необходимости второго крупного теплоисточника для г. Иркутска, и прежде всего в его правобережной части. Угольную ТЭЦ сооружать бессмысленно, так как нет возможности сооружения железнодорожной ветки на правый берег р. Ангары для подвоза угля. Строительство ТЭЦ на газе маловероятно из-за отсутствия сетевого газа (см. выше «газовые проблемы» ИО), а применение сжиженного углеводородного газа, который теоретически можно возить на автомобильном транспорте, сделает цену на тепловую энергию запредельной.

Проведенный анализ ситуации с ТЭК ИО показал, что существует много острых проблем, многие из которых должны были решаться ещё несколько лет назад. По мнению авторов, например, необходимо переработать ССЭР, увязав сценарии развития ИО с существующими реалиями, новыми тенденциями и вызовами, в том числе разделы относящиеся к ТЭК региона. Необходимо тщательно разработать отдельную стратегию развития ТЭК, как основу аналогичного раздела в ССЭР ИО, в которой бы детально рас- сматривались все составляющие ТЭК, в том числе достаточно конкретные планы реализации стратегии ТЭК и возможные источники её финансирования. Необходимо переработать устаревшую программу повышения энергосбережения и энергоэффективности ИО, которая должна определять эффективное производство и потребление энергоресурсов (включая холодную воду). К существующим в течение многих лет проблемам добавились новые вызовы и тенденции. Например, корпоративные процедуры, приведшие фактически к исчезновению крупнейшей компании «Иркутскэнерго». Передача всех ГЭС в «ЕвроСибэнерго-Гидрогенерация» и происходящая модернизация этих ГЭС, которая направлена на снижение себестоимости электроэнергии, имеет своей целью поднять их эффективность прежде всего в интересах алюминиевого бизнеса, но не ИО. Более того О.В. Дерипаска уже поднимал вопрос о необходимости повышения тарифов для населения ИО с целью снижения «перекрестного субсидирования». Проблема повышения тарифов (цен) на электроэнергию в целом для всех групп потребителей (включая население) ИО для «выравнивания цен (тарифов) в РФ», за последние два года стала подниматься на федеральном уровне (Совет Федерации РФ). При этом не ставится вопрос о «выравнивании социально-экономических условий» по регионам страны. Эти «намерения» становятся реальной угрозой для ИО. Не ясна ситуация с дальнейшим функционированием и развитием Байкальской энергетической компании (БЭК), которой передан весь «тепловой бизнес» бывшего «Иркутскэнерго». Можно предположить с большой степенью вероятности, что в будущем структуры «En+» (Евросибэнерго») постараются избавиться от своего высокозатратного «теплового бизнеса» (например, часть будет продана, часть перейдет в региональную и (или) муниципальную собственность), что неизбежно приведет к росту тарифов на тепловую энергию в ИО. В последнее время в ИО появилась «модная тема»- водородная энергетика, как «перспективное направление ИО, соответствующее мировым и отечественным трендам», которое поддерживается руководством ИО. Никто не оспаривает перспективность «водородной энергетики» в будущем, но в настоящее время это новое направление в ТЭК ИО вряд ли будет эффективным. Сторонники этого направления 
слишком упрощенно подходят к этой проблеме, заявляя, что в ИО много электроэнергии и воды, поэтому путем электролиза можно получать большие объемы водорода, в том числе и для его экспорта. Но в ИО нет большого количества дешевой, вырабатываемой на ГЭС электроэнергии, так как она практически полностью уходит на покрытие спроса алюминиевой промышленности. Поэтому необходимый объем электроэнергии пришлось бы производить на ТЭЦ, сжигая дорогой уголь и создавая дополнительные экологические проблемы. Более того, увеличивая выработку электроэнергии на ТЭЦ в конденсационном режиме, эти ТЭЦ будут работать неэффективно, так как все (кроме ТЭЦ-10) предназначены в первую очередь для нужд теплоснабжения. Итак, если перечисленные проблемы ТЭК ИО буду решаться хотя бы поэтапно, то энергетический комплекс региона станет действительно высокоэффективным, обеспечивая поступательное развитие всех составляющих экономики и социальной сферы ИО.

\section{СПИСОК ЛИТЕРАТУРЫ}

1. Топливно-энергетический комплекс Иркутской области: современное состояние и перспективы развития / под ред. Б.Г. Санеева, П.А. Воронина. М.: ИД «ЭНЕРГИЯ», 2013. - 304c.

2. Кутовой Г.П. Нужна новая парадигма (или архитектоника) экономических отношений в электроэнергетике // Энергетик. 2016. № 2. C. 8-13.

3. Головщиков В.О. Проблемы реформирования электроэнергетики в России и их влияние на рыночные отношения // Энергорынок. 2016. № 5. С. 30-35.

4. Кутовой Г.П. О необходимости продолжения реформ в электроэнергетике // Энергоэксперт. 2019. № 3. С. 18-25.

5. Жилкина Ю.А. Проблемы реформирования электроэнергетики в России // Энергетик. 2020. № 1. С. 29-32.

6. Стенников В.А., Головщиков В.О. Современные проблемы и пути преобразования электроэнергетики России // Энергетик. 2020. №6. C. 3-9.
7. Systems analysis of reform in Russia's energy industry. Stennikov Valery, Golovshchikov Vladimir E3S Web Conf. 289 01019 (2021), DOI: 10.1051/e3sconf/2021128 901019

8. Стенников В.А., Головщиков В.О. Розничный рынок электрической и тепловой энергии - проблемы и перспективы развития // Энергетик. 2019. № 6. С. 3-9.

9. Стенников В.А., Головщиков В.О., Романович Е.А. Нефтегазовая политика России в современных условиях и её особенности в Российско-Китайском сотрудничестве в газовой сфере //Вестник ИГТУ. 2021. Том 25, №1. С. 122-137.

10. Головщиков В.О., Огнев Д.В., Петрякова Е.А. Перспективы БАМа и Транссиба с учетом состояния регионов и развития угольной отрасли //Энергетическая политика. 2021. №2 (156). С. 30-43.

11. Головщиков В.О. Проблемы территориальных распределительных электросетевых компаний //Электроэнергия: передача и распределение. 2014. №3 (24). С. 114-119. 